\author{
TOMASZ BABNIS ID \\ JAGIELLONIAN UNIVERSITY, KRAKÓW
}

\title{
THE RIVER ARAXES IN THE ROMAN POETRY
}

\begin{abstract}
The Araxes flowing through the Armenian Highlands was one of the rivers mentioned quite often in Roman poetry from the Augustan Age up to the $5^{\text {th }}$ century. In line with the traditional tendency of classical literature, the Araxes was usually shown as a pars pro toto of a country, in this case Armenia, which was one of the aims of the Roman eastern policy and the object of rivalry between the Empire and Parthia/Persia. The great majority of references to the Araxes was connected with the theme of Roman expansion in the East (especially with the campaign of Tiberius in $20 \mathrm{BC}$ and later with the Roman-Parthian war 58-63 AD), which can be observed best in the recurrent motif of a bridge across this river, a clear-cut symbol of Roman domination over Armenia and - more generally - over all of the East.
\end{abstract}

KEY WORDS: Roman poetry, Roman policy in the East, Araxes, Armenia in Roman poetry, rivers in Roman poetry

\section{INTRODUCTION}

While referring to the mysterious world of the Orient, Latin poets used to reach for the names of rivers rather than for the names of cities. ${ }^{1}$ One

The first version of this paper was given during the meeting of Cracow branch of the Polish Philological Society 12 February 2019. I would like to thank all the par- 
reason for this choice was - amongst many other things - the great importance attached to rivers by ancient peoples. ${ }^{2}$ Rivers served as frontiers, trade routes and reservoirs of water needed in daily life. They were also connected with religious rituals and had a great symbolical importance. Some rivers became symbols of countries and nations, the Nile or the Tiber being a case in point. ${ }^{3}$ In Greek and Roman literature river water was a metaphor for movement and immutability. Poets used the names of rivers, especially the exotic ones, to show their acquaintance with geography, this way adding ornaments characteristic for poesis docta. Since the research on rivers in Latin poetry has developed considerably in recent years, I would like to complement it with an analysis of the mentions to one of the Eastern rivers surprisingly often referred to by the Latin poets, i.e. the river Araxes.

The Araxes (modern day Arax or Aras) is the second greatest river of the Armenian Highlands. With its total length of 1,072 km the Araxes rises near Erzurum in Turkey and flows eastwards in the direction of the Caspian Sea. It passes by three great lakes (Sevan, Van and Urmia) and finally flows into the Kura River near Sabirabad in Azerbaijan. In its middle course the Araxes marks out the frontiers of Turkey (with Armenia and the Nakhchivan Republic) and Iran (with the Nakchivan Republic, Armenia and Azerbaijan respectively). ${ }^{4}$

The Ancient Greeks reached the Araxes probably already in the archaic age, but first mentions in Greek literature come from the classical age. The lack of geographical precision triggered the wrong identification of this river: the Araxes was mistaken for some other rivers. In his description of the last campaign of Cyrus the Great, Herodotus (Hdt I 201-202; III 36) used the name Araxes instead of one of the rivers in

ticipants for their comments, questions and corrections which helped me improve my article.

2 Brian Campbell carried out a thorough analysis of many functions that rivers had in the ancient world. Though the title of his book puts an emphasis on the relations between rivers and power some other aspects are also covered in this book - Campbell 2012.

3 See for example the seminal work of Eleni Manolaraki on the Nile in the Greek and Roman literature from Lucan to Philostratus - Manolaraki 2013.

$4 \quad$ Fisher, Bosworth 1986. 
Central Asia, ${ }^{5}$ whereas Xenophon (Xen. Anab. I 5, 19) instead of the Mesopotamian river Khabur. According to scholars researching ancient geography, it was the conquests of Alexander and then the eastern expansion of the Roman Republic, that contributed to the growth of the knowledge of Western Asia. ${ }^{6}$ The Araxes was reached by Romans for the first time during the expeditions of Lucullus and Pompey. Waging war against Mithridates of Pontus, they conducted their campaigns also in Armenia. ${ }^{7}$ In all likelihood scholars of the $1^{\text {st }}$ century BC took advantage of these conquests and they succeeded in discovering the course of the Araxes and placed it more precisely on the map not later than in the end of that century. It is not unreasonable to link this process of discovering the region of Caucasus with the groups of Greek "experts" accompanying the Romans, Theophanes of Mytilene (in the milieu of Pompey) and later Crinagoras of Mytilene (in the army of Tiberius in $20 \mathrm{BC}$ ). In the Augustan age Strabo put it rightly on the map (Strab. XI 8,6) and Pomponius Mela, writing in the times of Claudius, added some important details (Pomp. Mela III 40). The Roman geographer accurately stressed the swiftness of the Araxes, reaching its highest point in spring after absorbing water from the melting snows in the mountains. What is also important, Pomponius Mela treated the Caspian Sea, into which the Araxes flows, as a part of the great Ocean. ${ }^{8}$ Thus the Araxes was perceived as a river at the end of the inhabited world (oikoumene), serving as one of

5 Herodotus probably meant the Amu Darya (Lat. Oxus). The Araxes was sometimes wrongly placed in Central Asia in later centuries: a prime example is so called Tabula Peutingeriana, on which it is the Syr Darya (Lat. Iaxartes) that is named Araxes - Arnaud 1993: 51. See also note 28.

$6 \quad$ See e.g. Cary, Warmington 1968: 326; Cattin 1963: 687-688; Dueck 2012: 2-3.

7 On the Armenian campaigns of Lucullus and Pompey see Cary, Warmington 1968: 326-333; Sherwin-White 1986: 195-203. In the context of the Araxes it is to be stressed that Pompey was said to have built the bridge across this river (App. Mithr. 103), like Alexander had been before him (Curt. Ruf. V 5), but it is not clear, if the Macedonian king's Araxes was the same river in Armenia (this is rather doubtful). The motif of the bridge across the Araxes was important in later Latin poetry. Cf. Watson 1997: 256, n. 341; Casamento 2013: 70-71.

8 The falseness of this theory was pointed out by Herodotus, but nevertheless this error was sometimes repeated even after the progress of geography, as we can observe it in Manilius' Astronomica (Man. IV 646-649). See Arnaud 1993: 50. 
the symbols of its edge. This perception should be kept in mind, while reading Latin poets writing on this Armenian river. ${ }^{9}$

Before proceeding to the analysis of the references to the Araxes in Roman poetry, we should make some introductory notes concerning rivers in Greek and Roman literature. Firstly, rivers often were used as a pars pro toto of the entire region or country. A prime example is Vergilian phrase Hinc movet Euphrates, illinc Germania bellum (Verg. Georg. I 509), in which Euphrates stands for Parthia, whereas Germania is referred to without any metonymy, or Horatian Medumque flumen gentibus additum / Victis minores volvere vertices (Hor. Carm. II 9, 21-22), in which the more ambivalent Medum flumen is again a symbol of the Parthian empire. ${ }^{10}$ A not uncommon variant of this figure is a longer periphrasis, wherein the inhabitants of given region are called "drinkers from the river X", usually the main river of a given region. A case in point is the Horatian discet Hiber Rhodanique potor (Hor. Carm. II 20, 20), where Rhodani potor is an inhabitant of Gaul, or the phrase from Martial's epigram et qui prima bibit deprensi flumina Nili (Mart. Spect. 3, 5), is a clear reference to an Egyptian. ${ }^{11}$ Secondly, because of the frequent use of rivers as natural frontiers, the names of rivers were treated as symbols of the end, edge or limiting the space. ${ }^{12}$ This sense appears in the Vergilian eclogue: Aut Ararim Parthus bibet, aut Germania Tigrim (Verg. Ecl. I 62). The names of the two rivers, Arar (modern Saône in France) in the west ${ }^{13}$ and Tigris in Mesopotamia in

\footnotetext{
9 The topic of the edges of the world is covered thoroughly by J.S. Romm (1992). Cf. Arnaud 1993: 51. In De fluviis ([Plut.] De fluv. 23) the Araxes is also mentioned, but its description is full of obscure pseudo-erudite information on the river's mythical past. Although the anonymous author underpinned his elucidation with some "bibliographical notes", the works he mentioned were made up by him (apart from De fluviis there is no reference to them). Thus, this passage is not affected by geographical and historical knowledge of the Araxes nor is influenced by the literary tradition.

10 It is worth noting that Medum flumen was sometimes understood as the Araxes. Generally, the majority of scholars speak for the Euphrates or the Tigris.

11 Cf. Campbell 2012: 127.

12 Thomas 1982: 3. This aspect was often covered by Lucan, especially in the description of Caesar's deeds.

13 Of course the Arar was not a border river of the Roman empire. The mentioning of the Arar instead of the Rhine is symptomatic of the Roman poet's lack of geographical precision. See also note 39 for more on this issue.
} 
the east, stand for two frontiers of the Roman empire and sensu largiore the edges of the world. ${ }^{14}$ The harnessing of the river, especially building a bridge across it, was treated as a synonym for the conquest of the given land. It also expressed the Roman rule over nature in general, as it can be seen in Caesar's description of the bridge across the Rhine (Caes. Gall. IV 17-18). Thirdly, from the times of Callimachus in Greek and Roman poetry the great Oriental rivers obtained a new, specific literary sense. Callimachus referred to the "Assyrian river" (usually considered to be the Euphrates) in his Hymn on Apollo (1. 107-112), as great but drawing much dirt. In this famous passage the poet from Cyrene voiced his aversion to the great epic poetry he wanted to avoid, instead advocating smaller poetic forms. Since Callimachean aesthetic ideas were an important factor in Latin poetry from the end of the Republican Age, the opposition between the epic and new poetry (symbolized in the opposition between the "Assyrian river" and the "holy spring") started to play an important role in the development of Latin literature. Those three factors are of particular importance, while discussing the functions of the poetic references to rivers, in this case of the Araxes. ${ }^{15}$

\section{AUgustan Age}

Even though the Romans reached the Araxes for the first time already during Lucullus' and Pompey's campaigns against Tigranes the Great in the $60 \mathrm{~s} \mathrm{BC}$, and then again during the occupation of Armenia by the forces of Mark Antony in 34-32 BC, it was only in the Augustan Age, when the first mention of this river appeared in Latin poetry. In the times of Augustus Armenia once more became the major issue in Roman eastern policy. Having consolidated his rule, in the 20s the princeps got involved in Armenian affairs which exerted a major impact on the political situation in this region. Both Rome and Parthia wanted to have their own candidate on the Armenian throne. The third book of Propertius' elegies

\footnotetext{
14 Romans used to fix their frontiers on the natural borders like great rivers (like the Rhine or the Danube) or mountains. Latin poetry also make references to this fact. However, those frontiers were not treated as something really stable and restraining Roman expansion - Arnaud 1993: 47; Pogorzelski 2011: 163.

15 Jones 1999: 110-111; Walde 2007: 67-71; Campbell 2012: 118-150.
} 
was published in 22 or $21 \mathrm{BC}$, i.e. in the time of growing tensions between the two empires and Roman preparations for war in the East. ${ }^{16}$ Since Propertius was strongly connected with the Maecenas' circle, we can observe a steady growth of interest in public and political issues in his poetry and that is why we encounter some passages referring to the ideas of eastern expansion in his third book. One of them is the first poetical reference to the Araxes. ${ }^{17}$ This mention is included in the first part of the elegy III 12, where the poet addressed one Postumus, who is leaving his wife Galla, so as to join the Roman army fighting the Parthians:

Tu tamen iniecta tectus, vesane, lacerna

Potabis galea fessus Araxis aquam.

Illa quidem interea fama tabescet inani,

Haec tua ne virtus fiat amara tibi,

Neve tua Medae laetentur caede sagittae,

Ferreus armato neu cataphractus equo,

Neve aliquid de te flendum referatur in urna:

Sic redeunt, illis qui cecidere locis.

(Prop. III 12, 7-14)

Propertius, though a member of Maecenas' circle, expressed his criticism towards the limitless eastern expansion of Rome in this elegy. He pointed out the lust for valuable loot (spoliati gloria Parthi, 1. 3) as a reason for the suffering of separated lovers. During the campaign Postumus is constantly in danger: Parthian riders and archers can easily take his life away. Although Propertius mentioned Parthians (1. 3) and Medians (1. 11) as the enemies of the Roman army, the only geographic indicator in these lines is the Araxes, which suggests that it is Armenia

16 The tensions between Rome and Parthia were finally resolved by the peace treaty concluded in $20 \mathrm{BC}$. Both sides made some concessions to each other but Augustan propaganda contrived to show this deal as a great success of the Roman army and diplomacy. Since thanks to this treaty the legionary signa lost by the Romans in the previous wars with Parthia were restored, Augustus could have claimed that the former defeats were avenged and the poets also contributed to this over-optimistic interpretation of the treaty - Sherwin-White 1984: 322-341; Babnis 2017.

17 It cannot be precisely determined if Propertius had written this elegy before Vergil wrote the ending of the eighth book of Aeneid. However, he had surely published the third book of his elegies before Vergil finished his opus magnum, and that is why this passage is analysed first. 
where the campaign should take place. Propertius replaced the name of a country with a name of its main river in accordance with the custom, thus suggesting the Roman offensive in Armenia as part of the great war in the East. The future tense (potabis, 1. 8) corresponds well with the expectations of the announced Oriental campaign. Drinking water from the river using a helmet clearly shows the military conquest of the land. This image not only indicates the Roman conquest, but also reaching a natural border recalling the end of the world. This distance and danger connected with the Armenian war puts an emphasis on the separation of Postumus and Galla (portrayed as a latter-day Odysseus and Penelope) and thus helps to clearly show the strength of their feelings. Propertius harmoniously united the elegiac and epic elements in the poem, giving preference to love over war. ${ }^{18}$

The second mention of the Araxes is placed in the elegy IV 3. This poem, treated as a prototype of the Ovidian heroid not without reason, has a similar ring to elegy III 12. In both pieces the main issue is the separation of a couple caused by war in the East, but in the later poem the main characters are called by the Greek names of Lycotas and Arethusa:

Noctibus hibernis castrensia pensa laboro

Et Tyria in clavos vellera secta tuos;

Et disco, qua parte fluat vincendus Araxes,

Quot sine aqua Parthus milia currat equus;

Cogor et e tabula pictos ediscere mundos,

Qualis et educti sit positura dei,

Quae tellus sit lenta gelu, quae putris ab aestu,

Ventus in Italiam qui bene vela ferat.

(Prop. IV 3, 33-40)

Arethusa is presented as an erudite reading scientific treaties on the world of the Orient and studying maps, but in first order as a loving wife awaiting her husband's return. The name Araxes, as in the elegy III 12, refers to Armenia as a place of Lycotas' sojourn. This is not the only correspondence between those two poems. Propertius once more announced the imminent conquest of this country: he treated it as a part of the great war against Parthians (mentioned several times in this elegy)

18 Wissemann 1982: 98-99; Babnis 2018b: 18-19. 
and perceived the Roman victory as something that is going to happen very soon. The epithet vincendus (1. 35) shows the inevitability of the conquest, whereas at the same time it can be treated as an indicator of the time of the creation of this piece. Although from 20 BC Armenia became a part of Roman sphere of influence after the successful campaign waged by Tiberius and the fourth book of Propertian elegies appeared after this year, probably in 16 BC. Elegy IV 3 seems to be written before this date and the phrase vincendus Araxes is the main argument for this dating. Had it been written after the Armenian campaign, the epithet vincendus would have been inappropriate or even somewhat shocking as an example of the undervaluation of Roman efforts in this region. That is why this poem should be placed amongst other elegies in the third book of Propertius: they reveal a common pattern, propagating the expansion of the empire to the east and supporting the solution of Parthian question by military expedition. Thanks to the reference to the Araxes, Arethusa is pictured as an erudite, in which she resembles the elegiac ideal of puella docta (often ascribed by Propertius to his mistress Cynthia). However, it is not only Arethusa but also the poet himself whom we may ascribe the label of an erudite, by dint of which he can be given a label of poeta doctus. One of the main arguments for obtaining this epithet was using exotic names, the then poorly known Araxes being one of them. ${ }^{19}$

If Propertius was the first Roman poet to mention the Araxes, it was definitely Vergil who created the most salient and the most influential image of this river. This mention is a part of the final part of the eighth book of Aeneid, in the famous description of Aeneas' shield. On this shield the god Vulcanus showed various events from Roman history, first and foremost the moments of greatest danger for the country. This long ecphrasis is closed with the description of Augustus' achievements: the victorious battle of Actium in $31 \mathrm{BC}$ and the three day triumph in 29 BC. The description of this triumphal procession (though not having much in common with real triumph of Augustus) include a lot of exotic geographical names shown on the tituli triumphales: ${ }^{20}$

19 Fischer 1968: 69-70, 80; Wissemann 1982: 100-101; Babnis 2018b: 20-21. According to Rudolf Fischer, the preference for using the names of exotic rivers is an important feature of Propertius' image of distant lands: cf. Fischer 1968: 52-74; 109-111. 20 The so called tituli triumphales (names of defeated peoples and countries often with accompanying images) were traditionally carried in Roman triumphal proces- 
Hic Nomadum genus et discinctos Mulciber Afros,

Hic Lelegas Carasque sagittiferosque Gelonos

Finxerat; Euphrates ibat iam mollior undis,

Extremique hominum Morini, Rhenusque bicornis, Indomitique Dahae, et pontem indignatus Araxes.

(Verg. Aen. VIII 724-728)

In these five lines Vergil mentioned three great liminal rivers: the Euphrates, the Rhine and the Araxes, ${ }^{21}$ as well as references to different peoples from all around the world. Andrew Feldherr rightly observed that in the eighth book of the Aeneid rivers play and important role serving as a framework for poetic narration: in the beginning of this book the riverine god of Tiber appears to Aeneas, whereas in the end the border rivers of the Roman empire are placed on Aeneas' shield. ${ }^{22}$ In the structure of the whole ecphrasis the distance between the Tiber and the eastern rivers does not only have a spatial, but also a temporal dimension. ${ }^{23}$ In this way Vergil emphasised the spread out over time territorial development from the small town on the Tiber through years of conquests to the great empire, the frontiers of which (equivalent to the frontiers of oikoumene) are marked out by the Rhine, the Euphrates and the Araxes. ${ }^{24}$ Two Oriental rivers are shown as subjugated: the Euphrates flows with humbler waves, and the Araxes has to endure the Roman bridge. The Armenian river is given the phrase pontem indignatus (1. 728), that shows also the Armenians' resistance to the expansion of Rome, the symbol of which is the bridge. The bridge across the Araxes was to be built by both Alexander and then by Pompey who tried to imitate the great Mac-

sions. They are sometimes referred to by the Roman poets: e.g. Incipiam et titulis oppida capta legam - Prop. III 4, 18; Cumque ducum titulis oppida capta leget - Ov. $T r$. IV 2, 20. Cf. Casamento 2013: 68-69. See also important paper on the triumph in Roman Erotic Elegy - Galinsky 1969.

${ }^{21}$ It is to be noted that another river mentioned in the final part of this book is the Nile (1. 711), the symbol of Egypt, Cleopatra's kingdom.

22 Feldherr 2014: 283-284.

23 Walde 2007: 70.

24 Hardie 1986: 355-357; Heckenlively 2013: 657-658. Crinagoras of Mytilene in his epigram (Anth. Planud. 61) written after his participation in Tiberius' expedition to Armenia used the names of the Rhine and the Araxes as the frontiers of the Roman empire as well. 
edonian king. It seems that this association was important for Vergil too, because it placed Augustan success amongst the great achievements of the former conquerors. In this passage the Araxes was used even more evidently in relation with Roman expansionism than in the elegies of Propertius. Admittedly, during the real triumph in $29 \mathrm{BC}$ the symbol of Araxes could not have been carried, as the former Roman attempts to conquer Armenia (campaign of Mark Antony in 34 BC and then rather obscure operations of Octavian during his stay in the eastern provinces after the battle of Actium) did not succeed. It was only after the expedition of Tiberius in 20 BC that Armenia really became part of the Roman sphere of influence. However, since Vergil was composing his opus magnum for many years, we may assume that he moved the subjection of Armenia a few years back. Thus he had an opportunity to praise Augustus for his policy more fully and to place his reign as a crowning achievement of the whole Roman history.

Apart from political connotations, the reference to the Araxes should be put under scrutiny from the point of view of its poetic meaning. Putting back the Callimachean meanings of the Euphrates, ${ }^{25}$ which in a way is a parallel to the Araxes, we may observe that the Armenian river is put at the very end of the ecphrasis. The ecphrasis itself (the topic covered by many scholars for many years ${ }^{26}$ ) poses questions about the relation between - on the one hand - text and image and - on the other hand between image and reality. Within the framework of this last opposition the bridge across the Araxes, the river flowing according to some ancient opinions into the Ocean, can be treated as a passage between those two spheres. As a result, the narration comes back from the description of the shield to the war, that was the reason why this weapon was forged. The

\footnotetext{
$25 \quad$ R.S. Scodel and R.F. Thomas observed that the Euphrates is mentioned three times in the poetry of Vergil. Every mention is placed in the sixth line from the end of the respective book, in the same place, where it was put by Callimachus in his aforementioned passage from the hymn on Apollo. This observations aroused a discussion on the meaning of this repetitive position and on the relations between Vergil and his Greek predecessor - Scodel, Thomas 1984; Clauss 1988; Jenkyns 1993.

$26 \quad$ See e.g. Harrison 1997; Heckenlively 2013; Feldherr 2014.
} 
war that, in a way is, the beginning of the long process of expansion that one day is going to reach the edge of the world. ${ }^{27}$

In the difficult to date third book of Corpus Tibullianum, containing poems of many authors connected after a fashion with Messalla's circle, we encounter the so-called panegyric on Messalla ([Tib.] III 7, sometimes referred to as [Tib.] IV 1). In this long hexametric poem we come across the last reference to the Araxes in the poetry of the Augustan Age:

Non te vicino remorabitur obvia Marte

Gallia nec latis audax Hispania terris

Nec fera Theraeo tellus obsessa colono,

Nec qua vel Nilus vel regia lympha Choaspes

Profluit aut rapidus, Cyri dementia, Gyndes, Aret Araccaeis aut unda Oroatia campis,

Nec qua regna vago Tomyris finivit Araxe, Impia nec saevis celebrans convivia mensis Ultima vicinus Phoebo tenet arva Padaeus, Quaque Hebrus Tanaisque Getas rigat atque Magynos. ([Tib.] III 7, 137-146)

The anonymous author of the panegyric put these lines in the lengthy passage on the martial achievements of Messalla (1. 82-176). He foretold the future triumphs of his patron, enumerating many lands and rivers from all the oikoumene. Some of them are taken from the territories of Achaemenid Persia and there is not even a shadow of doubt that they were taken from the account of Herodotus. The same goes with the reference to the Araxes. This river was put into the passage concerning the life of Cyrus the Great. The panegyrist took the whole story from Herodotus, and the line mentioning Araxes was a clear reference to the story of the abortive expedition against the Massagetae in Central Asia (Hdt I 205-214). During this campaign Cyrus was killed in the battle with forces of the queen Tomyris. The most puzzling thing is the geographical issue: the anonymous poet placed the Araxes in Central Asia, although in his times its proper location was already well known. Propertius and Vergil had placed it rightly in Armenia, whereas the panegyrist of

27 Fischer 1968: 32; Thomas 1982: 43-44; Wissemann 1982: 37-41; Jones 1999: 116; Casamento 2013: 69-73; Weeda 2015: 106-109. 
Messalla came back to the incorrect version of Herodotus, who mistook the Araxes for the Iaxartes or the Oxus, i.e. the main rivers of Central Asia (Hdt I 201-202). This passage in the panegyric on Messalla is the only example of the repetition of this Herodotean mistake in the works of Roman poets. ${ }^{28}$ Thus this reference lacks any stronger links with other poetic mentions of the Araxes (the only one similarity is a very general reference to the Roman expansion), being a surprising exception in the corpus of Latin poetry. ${ }^{29}$

\section{NERONIAN AND FLAVIAN AGE}

The reign of Nero (54-68 AD) was the time of a long Roman-Parthian war in Armenia. Vologases I (51-78 AD), king of Parthia, gave the Armenian throne to his younger brother Tiridates. Answering this challenge, the Romans entered Armenia. Armies of Gnaeus Domitius Corbulo conquered the entire country, by dint of which pro-Roman king Tigranes VI (60-63 AD) could enter the throne. The irresponsible politics of Tigranes, who invaded the Parthian vassal state of Adiabene, was the cause of another Parthian attack. Nero sent Lucius Caesennius Paetus to force the Parthians out of Armenia but his armies beleaguered near the city of Rhandea suffered a severe defeat. In the aftermath of the failed campaign, the Romans had to arrange peace. Under the conditions of the treaty of Rhandea (63 AD) Tiridates from the dynasty of Arsacids was to become the king of Armenia but it was Nero who was to crown him in Rome. This coronation took place only after three years but in spite of the imperial splendour of this feast, the Romans had to face the fact that they had lost effective control of Armenia. The country came back to the Parthian sphere of influence. The long war in Armenia, though

\footnotetext{
28 We encounter the placement of the Araxes in Central Asia by Roman poets again in two late antique works: Descriptio orbis terrae by Avienus ( $4^{\text {th }}$ century) and Periegesis by Priscian ( $6^{\text {th }}$ century). Both poets translated the Greek geographical work of Dionysius Periegetes (probably $2^{\text {nd }}$ century) and their mistake was taken from the original (why Dionysius made such an error is another question). Avienus (Avien. Descr. 917) and Priscian (Prisc. Per. 709) put the Araxes in the part of the work in which they describe the nomadic peoples of Central Asia.
}

29 Wissemann 1982: 104-107; Tränkle 1990: ad v. 140-146. 
eventually lost by the Romans, was the reason for greater interest in Armenian matters shown by the Roman poets. The case in point is the river Araxes that became one of the symbols of this country. Its mentions can be found in the works of Seneca and Lucan, active during the reign of Nero, as well as in the poetry of Statius who wrote his Silvae in the times of Domitian.

As a stoic philosopher interested in natural questions and the principal adviser of the emperor Nero obliged to exercise the external policy of the empire, Seneca was very knowledgeable about the world of the Orient. The Araxes was tightly connected with Roman operations during the Armenian war, so it is not surprising that it found its place among other Senecan references to the eastern world. Since the tragedies of Seneca are mythological plays, the references to current political issues (the war in Armenia being one of them ${ }^{30}$ ) are obviously treated in a different way than in the aforementioned phrases of Augustan poetry, but in spite of this differences they have a similar ring. ${ }^{31}$

In the second choral ode of his Oedipus, Seneca explored the wellknown Greek myth of Dionysus' expedition to India, the topic covered most completely in Nonnus' of Panopolis Dionysiaka. Latin poets often treated Dionysus' journey as a springboard for mentioning various exotic and not so familiar geographical names. ${ }^{32}$ In the Senecan Oedipus it is the Araxes that is to be mentioned in this way:

Vidit aurato residere curru,

Veste cum longa regere leones,

30 The absolute chronology of Seneca's plays is still sub iudice: while some scholars place their creation during the reign of Claudius, other link them with the Neronian Age. In my opinion, references to Armenian issues can be treated as a case for later dating.

31 This sort of geographical ornaments in Seneca's works is strongly connected with earlier literary tradition: "Sénèque ne fait que suivre le courant qu'avaient déjà suivi Virgile, Ovide, Horace, Lucain... Tradition née avec Homère, mais amplifiée par l'école alexandrine dont les oeuvres sont pleines d'érudition mythologique et géographique" Cattin 1963: 686.

32 Since Dionysus' eastern campaign was sometimes juxtaposed with the conquests of Alexander the Great (both expeditions reached India), the poets could have made use of this parallelism so as to praise the ruler for his - more or less imaginary - achievements in Oriental policy presenting the ruler as a new Alexander. 
Omnis Eoae plaga vasta terrae,

Qui bibit Gangen niveumque quisquis

Frangit Araxen.

(Sen. Oed.424-428)

The poet made use of references to the Indian Ganges and the Armenian Araxes so as to put emphasis on power of the deity and its formidable scope. Both rivers are part of a figure, by dint of which inhabitants of a given place are to be recalled. Ganges and Araxes, symbolizing India and Armenia, create not only eastern and western edges of the world of Orient, but they are also contrasted as far as climate is concerned. The Araxes is given the epithet niveus (1. 427) showing Armenian cold, while the Ganges recalls a hot climate. By means of this reference to climate the power of Dionysus is shown even more clearly. Auratus currus (1. 424) and longa vestis (1. 425) bring the triumphal imagery, core element of the Roman conception of imperial power, to mind. This phrase can be regarded as an allusion to the Vergilian image of pontem indignatus Araxes. The Senecan mention of the Araxes can be seen as a continuation of the Augustan ways of perception of this river with the addition of one specific feature, i.e. its coldness. ${ }^{33}$ As we are going to see hereinafter, both elements are to be taken into consideration in two other mentions of the Araxes in Seneca's tragedies. ${ }^{34}$

The Senecan Phaedra starts with the long hunting song (1. 1-84), in which Hippolytus sends out his companions, gives orders referring to hounds and equipment and finally turns to the goddess Diana, the patron of hunting. In this passage the poet included a lot of geographical names, starting from the region of Attica and then broadening the range of the hunt up to the edges of the oikoumene. In this last part of this song, the prayer to Diana, Hippolytus states that, in fact, almost the entire world is the domain of this goddess:

33 It appears that Seneca associates the swiftness of mountain rivers with its coldness - cf. Walde 2007: 75. On the other hand A. Cattin (1963: 700) suggested: "Pour cet espagnole habitué au climat méditerranéen, le froid, le neige, la glace font nécessairement partie d'un paysage des barbares". This statements is rather oversimplified, since in Senecan tragedies we encounter i.e. the hot land of India.

34 On geography in Seneca's tragedies see Cattin 1963; Syme 1987; Grant 2000. 
Ades en comiti, diva virago,

Cuius regno pars terrarum

Secreta vacat,

Cuius certis petitur telis

Fera quae gelidum potat Araxen

Et quae stanti ludit in Histro.

(Sen. Phaed. 54-59)

In the long catalogue of beasts falling prey ${ }^{35}$ to the hunting goddess, Hippolytus mentions also "the beast drinking from the cold Araxes". Although we do not know for sure which animal Seneca had in mind, it is more than probable that he mentioned a beast, which was imported to Rome for venationes in the capital. Thus, the mythological hunt of Hippolytus and his companions, who are sent to various parts of Attica, receives a kind of "expansion" adapted to the realities of Neronian Rome. The domain of Diana is then - on the metaphorical level - an area where the great hunt takes place: from every region the beasts come to Rome to be killed in the spectacles of death. Seneca was engaged with the issue of the influx of foreign goods (especially objects of luxury) and customs to the empire, which he considered to be dangerous consequence of limitless imperial expansion. Thus, even in mythological play the mention of Araxes is not totally unrelated to politics. Seneca reached out for the well-known motif of drinking from the river as a byword for a name of a specific region, but he transferred this activity, rather unconventionally, from people to animals. This is the only reference to this Armenian river in Latin poetry to be connected with the world of fauna. However, his interest in the natural questions, can be discerned in ascribing the epithet gelidus (1. 57) ${ }^{36}$ to the Araxes which the Augustan poets did not use. The coldness of the Araxes became its distinctive feature only in

\footnotetext{
35 "Diana, to whom Hippolytus prays, is exhibited by her worshipper as a goddess of death, not of life. The kingdom she rules is one of fear (esp. 72); the beasts who owe her allegiance she terrifies and kills (54-72)" - Boyle 1997: 62.

36 The similarity between gelidus in Phaedra and niveus in Oedipus is worth mentioning. This epithet in Phaedra was perhaps transferred from the name of the Danube, since this river was associated with cold since the publication of Ovid's exile poetry Grant 2000: 90.
} 
the poetry of Neronian Age. ${ }^{37}$ It appears that such a perception stemmed from the fact that this river flows for a greater part of its course through the mountains. In the tragedies of Seneca, the references to Armenia and Hyrcania, two countries that became important for Roman eastern policy in those days, are quite common. The reason for that was, in my opinion, the Roman-Parthian war in Armenia. By the dint of it the references to Armenia became more up to date in the years of Nero, so Seneca could have enumerated Araxes as a place, wherefrom the beasts for Roman venationes were imported. For his contemporaries gelidus Araxes was at the same time a symbol of the eastern expansion of Rome and of the influx of eastern goods to Rome. ${ }^{38}$

The problem of frontiers is referred to once again in the second choral ode of the Senecan Medea. Its theme is human tendency to travel which was aroused by the journey of the Argonauts. While in the golden age people did not sail and trade, the opening of the sea routes changed this state of affairs, and thus put an end to the previous age:

Terminus omnis motus et urbes

Muros terra posuere nova,

Nil qua fuerat sede reliquit

Pervius orbis:

\section{Indus gelidum potat Araxen,} Albin Persae Rhenumque bibunt.

(Sen. Med. 369-374)

Generally, the poet stated, that innate human desire to travel forces them to traverse lands and seas. The names of the rivers (the Araxes, the Elbe and the Rhine) emphasise the great distance between the places from which and to which people travel. Similarly to the aforementioned passage of Oedipus, the Araxes is given an epithet connected with temperature (gelidus, 1. 373) and is juxtaposed with the reference to India, thanks to that the climatic distinctiveness is shown clearly. What is more, travelling people (Indians to Armenia, Persians to Germania) move from east to west, in the same direction as the triumphant Dionysus on his way

37 Tacitus mentioned a very severe winter during the preparations for Armenian campaign made by Corbulo (Tac. Ann. XIII 35). Although it took place in Asia Minor, not in Armenia, it might have influenced Seneca and Lucan.

38 Axer 1991: 71-88 (no mention of the Armenian wars); Boyle 1997: 60-62. 
home after Oriental conquests. However, the most important thing about this passage is its clear-cut dependence on the famous lines from the first eclogue of Vergil: Aut Ararim Parthus bibet, aut Germania Tigrim (Verg. Ecl. I 62). ${ }^{39}$ If Vergil used this phrase as a part of adynaton figure, Seneca treated such a movement of people as if it was something real and obvious. New conditions, when every frontier was moved (terminus omnis motus, 1. 369), facilitate a great influx of alien people, goods and customs, which - as in the passage of Phaedra - is detrimental to the Roman empire. If thanks to sea routes cruel barbarian woman could have reached Greece, other dangers could as well. Since travelling opened the door to trade, it opened it to greed and luxury as well. The imperial expansion is driven by those lusts, endangering Roman morality. The chorus then poses a question about the limits of expansion and its harmful effects. As Colchis, homeland of Medea, lies close to Armenia, symbolised by the Araxes, we can assume that Seneca alluded here also to the Roman-Parthian power struggle for this country. ${ }^{40}$

Seneca's nephew Lucan was much more disapproving of the principate (and Nero's rule in particular) than his uncle ever had been. In Pharsalia Lucan castigated his fellow countrymen for letting the civil wars happen and for not undertaking the war against Parthia (this idea can be seen also in Horace's early works). This belief is mentioned many times in the work but is voiced for the first time already in the very beginning of the first book, just after its prooemium: Sub iuga iam Seres, iam barbarus isset Araxes, / Et gens si qua iacet nascenti conscia Nilo. (Luc. I 19-20). Lucan implied that had the civil war not happened, the Romans would have conquered great areas in Asia and Africa. The extent of this conquest is suggested by the mention of Seres (Chinese), Araxes (Armenia) and Nilus (Egypt). As we can see from this short passage, Lucan had an inclination towards using the names of rivers: in his Pharsalia he enumerated a great number of them (ca. 90 names, ca. 250

\footnotetext{
39 In this place we should report the suggestion of K. Wellesley, who tried to emend the text of this eclogue, so as the river representing Germania be not the Arar, but - as it is in Medea - the Rhine. One of his arguments, also in relation with the passage from Seneca's tragedy, is another emendation from Oaxes to Araxes in 1.65 of this eclogue Wellesley 1968.
}

$40 \quad$ Romm 1992: 168-172; Boyle 1997: 127-128; Benton 2003: 281-283. 
mentions) with a much greater frequency than other epic poets. ${ }^{41}$ The Araxes is one of those rivers and Lucan mentioned it three times in total. ${ }^{42}$ As in the case of Seneca, we may assume that the reason for this was the long Roman-Parthian war in Armenia. Lucan made use of the image of yoke (iuga, 1. 19), that was perceived as a symbol of subjection to Roman rule. The yoke can be then understood in the same way as the bridge in the passage from Aeneid. ${ }^{43}$ The triumphal imagery is again suggested, ${ }^{44}$ but Vergilian optimism is completely absent from Lucan's statement. The author of Pharsalia tried to show that the myth of Rome created as a justification for the principate is a lie and Augustan achievements were in fact short-lived, which can easily be seen in the Oriental policy. The immensity of lost chance in Armenia is emphasised by the geographical extent of conquests not carried out and thanks to it the evil of the civil war is shown even clearer. The poet added the adjective barbarus to the name of the river, a rather vague and general term, but presenting Armenia (the Araxes is surely its pars pro toto ${ }^{45}$ ) as a hostile land. ${ }^{46}$

In the seventh book of Pharsalia, just before the description of the battle of Pharsalus, Lucan discussed various bad omens (prodigia) connected with fratricidal fight and reaction to them in the camps of Caesar and Pompey. Summing up all this sad events, he stated:

41 On rivers in Lucan's work see: Mendell 1942; Walde 2007; Manolaraki 2013: 45-117; Bexley 2014: 389-395. R. Pogorzelski (2011: 143) stated in more general terms: "Lucan's Bellum Civile is an intensively geographical poem".

42 Generally, Lucan referred chiefly to rivers being close to the route of Caesar's and Pompey's armies (Walde 2007: 63). The Araxes is not the case in this respect.

43 Lucan made use of the image of a bridge across the river as a symbol of its subjugation in the episode of Corfinium (Luc. II 478-504) - Walde 2007: 74.

44 Civil wars are yet described by Lucan as bella [...] nullos habitura triumphos (Luc. I 12).

45 It was observed already by late antique commentators, since in Commenta Bernensia (ad v. I 19) we read: IAM BARBARUS ISSET ARAXES $\mu \varepsilon \tau \omega v v \mu \imath \kappa \tilde{\omega} \varsigma$ pro incolis. Est Araxes Armeniae fluuius.

46 Pogorzelski 2011: 150-153; Casamento 2013 (esp. 57-65, 75-77). There is also another interpretation, according to which the beginning of the Pharsalia is a sincere praise of Nero: in that event these lines should be read as a sign of incentive to carry on the policy of expansion in the East. 


\section{Tyriis qui Gadibus hospes}

\section{Adiacet, Armeniumque bibit Romanus Araxen:}

Sub quocumque die, quocumque est sidere mundi,

Maeret, et ignorat causas, animumque dolentem

Corripit; Emathiis quid perdat nescit in arvis.

(Luc. VII 187-191)

The poet referred to prodigia as a sign of disaster not only for the soldiers waiting for the battle but also for the whole world. Romans, wherever they are, feel the fear of the coming fight. Lucan mentioned two geographic names from the westernmost (Gades in Hispania) and easternmost (Armenia) regions of the Roman empire. Although the status of those two places is not the same, since Hispania is a Roman province, whereas Armenia is - at best - one of the client kingdoms lying in the Roman sphere of influence, Gades and the Araxes are in a way on the same level, when it comes to their geographical location. They are both very close to the edges of the oikoumene: the former to the Atlantic Ocean, the latter to the Caspian Sea and the eastern part of the Ocean. By dint of this geographical extent, Lucan could again have shown that the Roman civil war is in fact a world war. The Araxes is in this passage together the symbol of Armenia ${ }^{47}$ and the frontier of the inhabited world. Since in 48 BC the Romans were not active in Armenia, we may assume that this mention of the river is an allusion to the Roman-Parthian war in the times of Nero. ${ }^{48}$

The eighth book of Pharsalia contains the largest and the most detailed discussion of Parthians in the extant Latin poetry. The opportunity for such a discussion was enabled by the result of the battle of Pharsalus that made Pompey look for an Eastern ally. The debate, if the defeated leader should go to Parthia or to Egypt, took place in Cilician Syhedra. ${ }^{49}$ Pompey advocated the Parthian direction, based on his former relations

\footnotetext{
47 Although the Araxes is very often pars pro toto of Armenia, this passage in the seventh book of Pharsalia is the only case, when the river's name is accompanied by the epithet Armenius.

48 Bexley 2014: 390-391. See also Nabel 2019 (thorough an analysis of the reflection of the Armenian war in the age of Nero in Lucan's work).

49 The actual debate that took place in Syhedra had a different course - Hillman 1996.
} 
with the Arsacid king Phraates III and the treaty concluded with him in $63 \mathrm{BC}$. The consul Lentulus - in turn - suggested to go to Egypt and therefor gave many arguments against going to Parthia. ${ }^{50}$ His speech about the Parthian customs is a splendid example of inclusion of the ethnographic tradition into the epic. Lentulus often refers to the defeat of Crassus in the battle of Carrhae, thus alluding to the issue outlined in the aforementioned passage of the first book, i.e. to the need of revenge on Parthians. The most interesting part of his utterance is the recalling of the ghost of killed Crassus: ${ }^{51}$

Non tibi, cum primum gelidum transibis Araxen,

Umbra senis maesti Scythicis confixa sagittis

Ingeret has voces? "Tu, quem post funera nostra

Ultorem cinerum nudae speravimus umbrae, Ad foedus pacemque venis?

(Luc. VIII 431-435)

"The shadow of the sad old man" expresses his disappointment with the behaviour of Pompey, who is willing to make an alliance with the Arsacids instead of revenging the Roman cause. ${ }^{52}$ In these lines Lucan ascribed a specific meaning of a Roman-Parthian frontier to the Araxes, though it never served as such. It is hard to imagine Pompey going to Parthia through Armenia and it appears that the Euphrates or the Tigris

50 J. Nabel is right, when he stated that Lentulus speaks much more against the Parthian direction than for the Egyptian one: "Parthia dominates the discussion" - Nabel 2019: 605 .

51 Employment of the ghost speaking to the living is a standard epic motif. Lucan made use of it in the third book, when Julia, his dead wife and daughter of Caesar, appeared to Pompey. In Pharsalia the poet reached for the motif of the ghost of two persons whom he ascribed the delaying of the outbreak of war between Caesar and Pompey. On ghosts in Lucan's work see Bernstein 2011.

52 This opinion make a strong contrast with Pompey's statements that it was he who stopped the Roman revenge right after the battle (Quis enim post vulnera cladis / Assyriae iustas Latii compescuit iras? - VIII 233-234). The transformation of Pompey from the republican leader to Oriental despot is one of the most important aspects of Pharsalia - Hodges 2004: 121-151. 
would be a better choice as a riverine frontier of the Arsacid empire. ${ }^{53}$ This lack of geographical precision, common to Latin poets writing about the Orient, seems to stem again from the Roman-Parthian war in Armenia during the reign of Nero. The meaning of the crossing of the frontier is important in this passage, since Pompey is shown as a transgressor the way Caesar is in the first book, while crossing the Rubicon. Lentulus juxtaposes both commanders in their activities that harm the Republic: searching for an alliance with Parthia is, in his opinion, equally dangerous as overthrowing the republican system (cf. Ad Parthos, qui vicit, eat. Gens unica mundi est, / De qua Caesareis possim gaudere triumphis, 1. 429-430). All of Lentulus' speech helps to present the change that happened to Pompey, who ceased to be the man devoted to Republic that he had been before, and became the selfish loser paying no attention to the needs of the state and his own people. The Araxes serves then as a frontier: to cross it means to dissociate from the Roman world. ${ }^{54}$

Amongst the Flavian poets it was Statius who mentioned the Araxes three times in his Silvae. First of these mentions appears in Silvae I 4, soteria directed to twice consul and praefectus Urbi Rutilius Gallicus. The addressee served as a governor of Galatia in the times of Nero, being active also in Armenia:

Hunc Galatea vigens ausa est incessere bello - me quoque - perque novem timuit Pamphylia messes

Pannoniusque ferox arcuque horrenda fugaci Armenia et patiens Latii iam pontis Araxes.

(Stat. Silv. I 4, 76-79)

In these lines the Araxes is mentioned along the name of Armenia but is clearly another symbol of that land. The image of Armenia is definitely connected with military issues, since the activities of Gallicus had to be connected with the war in the 50 s and $60 \mathrm{~s}$, which is emphasised also by

53 However, one should bear in mind that these rivers appear in one of the next lines (Obruit Euphrates, et nostra cadavera Tigris, 1. 438). Crassus crossed the Euphrates to find death on Parthian territory and the appearance of his ghost is a warning to Pompey so as not to follow his example. Ironically, it is Lentulus' advice, that aims to save Pompey from danger, that is going to lead the commander to death in Egypt.

54 Walde 2007: 73; Pogorzelski 2011: 154-164; Nabel 2019: 614-615. 
the use of apposition arcuque horrenda fugaci (1. 78) - a clear-cut reference to the Parthian martial custom - accompanying the name Armenia. Statius is the first Latin poet who unequivocally referred to the Vergilian image of pontem indignatus Araxes (Verg. Aen. VIII 728). When Vergil tried to show this river as a symbol of recalcitrant Armenia subjugated by Augustus, Statius did the same, but in the case of Domitian there was no reason for that, since after the treaty of Rhandea Armenian lands had been definitely part of the Parthian sphere of influence. ${ }^{55}$ According to Statius, the Romans succeeded in Armenia during the reign of Domitian (iam, 1. 79), though earlier the Roman control of this land, symbolised by the bridge across the Araxes, had not been so strong. It should be noted that the poet made a shift from the times of Nero (when Gallicus was actually active in the vicinity of Armenia) to the times of Domitian (when Araxes, i.e. Armenia, was allegedly subordinated to Rome). Intertextual reference to the work of Vergil aims at making the ruling emperor the follower not only of the first princeps but also of Alexander and Pompey, who - according to literary tradition - built a bridge across the Araxes before. Seen from this perspective, the Araxes serves to create a positive image of Domitian as a conqueror of the East. ${ }^{56}$

Silvae V 2 was addressed to the young Crispinus, son of Vettius Bolanus, the consul of $66 \mathrm{AD}$, another man of state engaged in the Armenian war (cf. Tac. Ann. XV 3). A part of the poem is dedicated to that very issue:

... sed enim tibi magna parabat

Ad titulos exempla pater, quippe ille iuventam

Protinus ingrediens pharetratum invasit Araxen

Belliger indocilemque fero servire Neroni

Armeniam, rigidi summam Mavortis agebat

Corbulo, sed comitem belli sociumque laborum

Ille quoque egregiis multum miratus in armis

Bolanum;

(Stat. Silv. V 2, 30-37)

\footnotetext{
55 However, Vespasian strengthened the position in the Anatolia and Syria thanks to reorganization of provinces and vassal kingdoms: Babnis 2018a: 6-7.

56 Casamento 2013: 69-70; Babnis 2018a: 15-16.
} 
As in the poem to Rutilius Gallicus, Statius juxtaposed the names of Araxes and Armenia, while referring to Bolanus' activities in this land. Another similarity between these two pieces is the mention of archery, so important in the Parthian army. The epithet pharetratus is associated with the name Araxes, showing that from the Roman point of view there was no essential difference between Armenians and Parthians. Statius made this river a frontier of Armenia that Bolanus once had crossed, but - contrary to Lucan's Pompey - this crossing is perceived as a claim to fame for the hero. In the further part of the poem Statius addressed Crispinus himself, wishing him to become famous as a commander or governor in the regions that had seen his father before: Quod si te magno tellus frenata parenti / Accipiat, quantum ferus exsultabit Araxes! (1. 141-142). The poet placed an emphasis of the former conquest of Armenia by Bolanus (tellus frenata, 1. 141), which - as mentioned above is definitely a far-fetched statement. It is the only passage in Latin poetry, when the Araxes is ascribed some positive feelings. ${ }^{57}$ According to this phrase, the Roman rule can be profitable for the foreign land, even a wild (ferus, 1. 142) one. Again we can observe the similarity between this poem and Silvae I 4: praising the addressee, Statius praised the emperor too, and the extent of laudatory statements seemed not to contradict the vagueness of the actual achievements of Rome in the East. ${ }^{58}$

\section{LATE ANTIQUITY}

The first poet to mention the Araxes after Statius was Claudian, who did so only after three centuries. The political situation in Armenia at the turn of the $4^{\text {th }}$ and $5^{\text {th }}$ century was completely different than in the age of Nero or Domitian. When Sasanians took power in Iran, Armenia ruled on and off by the Parthian dynasty of Arsacids started to get closer to

57 Of course from the etymological point of view, exsultare comes from saltare (to jump) and can be labelled a verb of movement. Those kinds of verbs (e.g. fluere) are often used in the case of rivers and the mentions of the Araxes follow suit. Since Bolanus was active not only in Armenia, but also in Britannia, the juxtaposition of Araxes and Caledonia (1. 141-142) skilfully shows the two most remote boundaries of the Roman empire - Gibson 2009: ad v. 141.

58 Gibson 2009: ad v. 32, 141; Babnis 2018a: 23-24. 
Rome, especially after the Christianisation of both the empire and Armenia that took place at the beginning of the $4^{\text {th }}$ century. About 387 Roman Emperor Theodosius reached an agreement with Persian King Shapur III and they divided Armenia into two parts: the western part fell under Roman rule, while the eastern part became the vassal kingdom of Persia. This partition was advantageous to Roman-Persian relations which in the $5^{\text {th }}$ century had a more peaceful course than before. ${ }^{59}$ The Roman empire in the years of Claudian's activity (394-404) did not deal with the aggressive politics of Persia. What is more, the poet who in spite of his Graeco-Egyptian descent was active only in Italy at the court of Theodosius I and Honorius treated Oriental (e.g. Persian and Armenian) issues surprisingly often. ${ }^{60}$ Being a panegyrist of Rome and the generalissimo Stilicho, Claudian often referred to the future glory of the empire and its eastern conquests. The references to the Araxes in his poetry, five in total, are placed against such a background.

Claudian was a careful reader and in a way a follower of Statius. As the Flavian poet wrote laudatory poems to Emperor Domitian, so did Claudian to Theodosius I, Honorius, Stilicho and aristocrats from the western part of the empire. His poetry was pervaded by the idea of the eternal Rome ${ }^{61}$ the important part of which was the concept of the Roman rule over the East, irresistible dream of generations of commanders and emperors wanting to follow Alexander the Great. What is important for our analysis, the eastern countries are often referred to using the names of rivers. ${ }^{62}$ Already in his first panegyric, the praise of consul brothers Probinus and Olybrius performed 1 I 395, Claudian reached for this idea, also mentioning the Araxes among other geographical names:

Adnue: sic nobis Scythicus famuletur Araxes,

Sic Rhenus per utrumque latus, Medisque subactis

\footnotetext{
$59 \quad$ Blockley 1987.

60 One could argue that from the point of view of the imperial court in Italy Persia (and Armenia in like manner) never have been so "distant" from Rome. However, it is Claudian's and Sidonius' poetry in which we come across the most examples of references - sometimes very original and not known from the earlier poetry - to the Iranian world.

${ }_{61}$ See Brodka 1998 (on Claudian: 91-118).

62 Brodka 1998: 103.
} 
Nostra Semiramiae timeant insignia turres;

Sic fluat attonitus Romana per oppida Ganges.'

(Claud. Prob. et Olyb. 160-163)

These four lines is a part of a dialogue between Emperor Theodosius I and the goddess Roma, the personification of Rome. ${ }^{63}$ The ruler seeks the advice of the goddess, asking about the right course of his next activities (after the victory over the usurper Eugenius in the battle of Frigidus in 394). Roma suggests he give consulate to Probinus and Olybrius, which will surely help the empire in the process of conquering barbarian peoples. The Araxes this time seems not to be pars pro toto of Armenia or Persia (the symbol of the latter is Babylon - Semiramiae turres, 1. 162) but rather as a frontier of a future empire extended eastwards along the Rhine and the Ganges. ${ }^{64}$ A rare epithet Scythicus may refer to the Huns, who at the end of the $4^{\text {th }}$ century were active in the Caspian region and posed a threat to the eastern provinces of the empire. ${ }^{65}$ Generally, all these geographical names symbolise the lands that should be captured by Rome and again - as in the case of Statius - none of them were really to be conquered by the emperor, whom the poet linked with these achievements. What is more, both emperors died soon after the respective poems had been written.

The invective In Rufinum written in 396-397 offers a similar image of Araxes as a part of the Roman empire extended by new conquests. Since

63 Claudian showed a tendency towards the employment of supernatural characters, especially deities and personification. The goddess Roma is one of the most prominent in their number. The Araxes (the same goes with many other places from the eastern world) is mentioned by Roma three times out of five mentions in Claudian's poetry. This important role of supernatural characters praising the emperor and his trusted advisors can already be seen in the Silvae of Statius. Prime examples are the speeches: of Apollo in I 4 and of Janus in IV 1. Cf. "Roma is a star among a permanent company of personifications" - Kelly 2013: 177.

64 We already noticed that the Araxes is mentioned with other rivers: in Vergil with the Rhine, in Seneca with the Rhine and the Ganges.

65 Such an invasion really took place in 398, when the Huns passed through Caucasus and Armenia and attacked the Anatolian provinces. They were defeated by Eutropius who was awarded consulate in 399 for this achievement. Claudian mocked this victory but alluded - as it seems - to the still dangerous presence of the Huns in the Caspian region in second book of his "In Eutropium" (see below). 
Rufinus was the praefectus praetorio at the court in Constantinople and the enemy of politics of unification conducted by Stilicho, Claudian stated that this successful period in Roman history is to begin soon. After the assassination of Rufinus in 395 Stilicho could have hoped for extending his "protection" to Arcadius, ruling in the eastern part of the empire, and therefore greater optimism concerning the eastern expansion of Rome:

Iamque aderit laeto promissus Honorius aevo

$\mathrm{Nec}$ forti genitore minor nec fratre corusco,

Qui subiget Medos, qui cuspide proteret Indos.

Sub iuga venturi reges; calcabitur asper

Phasis equo pontemque pati cogetur Araxes,

Tuque simul gravibus ferri religata catenis

Expellere die debellatasque draconum

Tonsa comas imo barathri claudere recessu.

(Claud. In Ruf. I 372-379)

As in the panegyric on Probinus and Olybrius it is the goddess (this time Iustitia, not Roma) who announces the future achievements in the East. In the laetum aevum of Honorius the Romans are to extend their rule over the entire oikoumene. ${ }^{66}$ The Araxes is mentioned with other eastern names: Medians (i.e. Persians), Indians and the river Phasis in Colchis. One should not omit the important allusion to Vergilian pontem indignatus Araxes that is easily discernible in the phrase pontemque pati cogetur Araxes. However, the idea of the bridge across the Araxes seems to be taken not only from Aeneid, but also from Statius' Silvae I 4: patiens Latii iam pontis Araxes. The Augustan poet put an emphasis on the resistance of the river, whereas his successors stressed the Roman rule (the verb pati, in Claudian's poem additionally strengthened by cogetur, clear-cut indicator of coercion). While Vergil's statement was, after a fashion, justified in light of Augustus' eastern politics, this justification was getting weaker when it comes to the poem of Statius, let alone of Claudian. The Vergilian idea of bridge across the Araxes was surely a laudatory one from its very beginning, but over the centuries

66 We find here a clear reference to the idea of aurea aetas. The successful reign of Honorius is posed as the reign of Augustus was several centuries before. The implementation of this ideal is described in the last part of the first book of In Rufinum - Ware 2012: 218. 
the intensity of panegyrism grew enormously, despite the evident lack of Oriental triumphs. The appearance of this name lost any contact with the real political and military plans of the emperor, ${ }^{67}$ being degraded to a mere ornament contrasting not only the aims, but also the possibilities of the Roman empire. This tendency, observed here in connection with the name of the Araxes, can be applied to many other eastern geographical and ethnic names that appear in postclassical Latin poetry. ${ }^{68}$

The emperor Honorius held his fourth consulate in 398 in the age of 14 and Claudian honoured this fact with another panegyric. ${ }^{69}$ Since the lack of great deeds of the honorand posed a problem to the panegyrist, the great part of this poem in dedicated to the military achievements of the late emperor Theodosius I, who died 17 I 395: the facts from Honorius' life are set against this background. The long speech of the emperor (1. 203-352), in which he advises his son how to rule the empire, is placed before the expedition against the usurper Eugenius in 394. Therefore, Honorius is shown only as an 11 year old boy too keen to take part in the forthcoming campaign and it is not surprising that the father suggests him to rest on Stilicho, while the emperor sets out to war. The time for the boy - whose precocious interest in war is similar to the behaviour of Statian Achilles - to wage a war is yet to come:

\section{Sed proelia differ}

In iuvenem patiensque meum cum fratre tuere

Me bellante locum, vos impacatus Araxes, Vos celer Euphrates timeat, sit Nilus ubique Vester et emisso quidquid sol imbuit ortu.

(Claud. IV Cons. 385-389)

\footnotetext{
${ }^{67}$ Of course in Augustan poetry there were also some ethnic and geographical names that were mentioned as a future prey of Roman expansion, though being absolutely out of its reach, but at least Armenia was not one of them and the Romans were very active in the region of Caucasus.

${ }_{68}$ Levy 1971: ad v. 368-387; Ware 2012: 281.

69 In this panegyric the Statian figures (Achilles and Parthenopaeus) are used as models for young Honorius - Parkes 2005. Cf. also Kelly 2013: 174.
} 
Advice from Theodosius I is directed first only to Honorius, but then to his older brother Arcadius as well. ${ }^{70}$ For the time being they both should rely on more experienced persons, but the older emperor expresses a wish that they will make the Euphrates and the Araxes tremble and rule over the Nile. The juxtaposition of those three rivers, two of which were regarded as frontiers, although the latter definitely not, is somewhat puzzling. Normally, the Euphrates and the Araxes are linked with conquests of the East and the context of the whole speech seems to suggest that they should be understood as a frontier region of the empire. The verb timere (1. 388) should therefore be translated as "to respect", while the epithet impacatus (1.387) is to be linked with the situation in Armenia, on the one hand endangered by the Huns, on the other hand still unquiet after the Roman-Persian partition. The Araxes again is a pars pro toto of the entire country, but this reference contains some reflexes of the Vergilian image of the turbulent river. ${ }^{71}$

The rebellion of Gildo, the governor of Africa, in 398 gave Claudian an impulse to write De bello Gildonico, an untypical mixture of martial epic and invective. ${ }^{72}$ Since Gildo stopped the deliveries of African grain to Rome, his defection posed a great threat to the western half of the empire. ${ }^{73}$ Claudian took this danger into consideration in his poem. It is again the goddess Roma - who utters the statement that encompasses the reference to the Araxes set at the background of the supply problems in Italy. The goddess addresses Jupiter, pleading him just for grain (pabula tantum, 1. 34):

\section{Advenio supplex, non ut proculcet Araxen}

Consul ovans nostraeve premant pharetrata secures

Susa, nec ut Rubris aquilas figamus harenis.

\footnotetext{
70 Although Arcadius was 21 in 398, Stilicho still hoped to become regent of the eastern part of the empire too. Admittedly, the verb differ is a singular form, but then there is a plural vos and vester, which also suggests that the elder son should follow the father's advice. The fact that this speech is placed in 394 (so Arcadius is 17) strengthens Stilicho's claim.

71 Parkes 2005: 74, 81.

72 On the generic equivocality of this poem see Garambois-Vasquez 2007: 20-40

73 Gildo as tyrannus - Ware 2004; Ware 2012: 148-170. On three enemies of Claudian/Stilicho (Rufinus, Gildo, Eutropius) see Garambois-Vasquez 2007: 212-223.
} 
Haec nobis, haec ante dabas; nunc pabula tantum Roma precor.

(Claud. Gild. 31-35)

Claudian stressed the contrast between the current hardship (nunc, 1. 34) and erstwhile military achievements (ante, 1. 34). Roma's request does not concern great conquest in the East, but a mere survival. The Araxes is listed among Oriental names, as it happens frequently, along a conventional reference to the Persian empire (pharetrata ... Susa, 1. 32-33), but this time it appears in a longer sentence: the goddess presents an image of a Roman consul trampling the river. Since the verb proculcare (1.31) has a semantic nuance connecting it with the concept of pride and might ${ }^{74}$ and ovare (1.32) is almost a byword for triumphare, Claudian managed to point out the contrast between the crossing of the Araxes and the words supplex (1.31) and precor (1.35) describing Roma. In this passage the Armenian river is again a line to be crossed on the way to great conquests. According to Roma the present state of the empire does not allow to think of anything more than a fight for survival, so the victory over Gildo that was gained by Stilicho's subaltern Mascezel (Gildo's brother) seems to be unexpected and thus the success of Stilicho is given additional praise. ${ }^{75}$

The pessimistic overtone of the reference to the Araxes in De bello Gildonico finds the parallel in the second book of In Eutropium, another of Claudian's invectives addressed against the eastern Roman politician. The eunuch Eutropius was another of Stilicho's enemies active at the court of Arcadius (although it seems that they had cooperated in removing Rufinus), who managed to fight off the invasion of the Huns in 398 and was rewarded with consulate in 399 . His spectacular rise caused a crisis in relations between Milan and Constantinople, but the tensions were soon relieved, when Eutropius was deposed and exiled after the revolt of the allied Goths troops. Since the book was composed already after his fall, the poet could have ascribed all the shortcomings and failures to him. Claudian made use once again of the personification, this

\footnotetext{
74 This verb is rather rarely used by earlier poets, though it is quite frequent in Claudian - Cuzzone 2006/2007: ad v. 31.

75 Cuzzone 2006/2007: ad v. 31-33.
} 
time Aurora, the goddess of the East (i.e. Constantinople), whose speech closes the poem. She addresses Stilicho, pleading him to help the eastern part of the empire desolated after the impious consulate of Eutropius:

\section{Nuper ab extremo veniens equitatus Araxe}

Terruit Antiochi muros, ipsumque decorae

Paene caput Syriae flammis hostilibus arsit.

(Claud. In Eutr. II 569-571)

Amongst the many hardships the empire has to face Claudian listed an invasion from behind the Araxes that had reached Antioch. Although it is hard to state with certainty which invasion the poet had in mind, it is no nonsense to think about the Hunnic attacks from the region of Caucasus. Eutropius fought off one of such incursions in 398, but there could have been more attacks like this. ${ }^{76}$ The mention of Antioch brings to mind the Persian invasions of the $3^{\text {rd }}$ and $6^{\text {th }}$ centuries, when the Syrian capital fell prey to - respectively - Shapur I and Khosrow I. This time I would rather see the mounted Huns in equitatus (1. 569), since the Persian frontier at the end of the $4^{\text {th }}$ century was comparatively quiet. The epithet extremus (1. 569) is rather surprising as an attribute of the Araxes: it could be interpreted as an intensification of the impression of eastern Rome's weakness. If the enemies could have made an incursion from behind the distant river and no one had the strength to stop them, the crisis had to be really serious. This interpretation is in line with the general tenor of the poem, that Stilicho is the only hope (Iam sola renidet / In Stilichone salus, 1. 501-502) for both parts of the empire to surmount the impending internal and external difficulties.

It is a fair statement that Claudian lived in the circumstances that were not favourable for writing about eastern triumphs of Rome, but it is even more true in the case of Sidonius Apollinaris. This $5^{\text {th }}$-century poet from Gaul, a relative and eulogist of ephemeral emperors of this age, showed surprising interest in Oriental matters. ${ }^{77}$ What is more, he knew

76 Some Claudian's statements referring to the threats to the Roman empire, e.g. the announcement of the hostile stance of the new Persian King Yazdegerd I (399-421), was probably fabricated by him to denigrate Eutropius.

77 Sidonius is the only Roman poet to mention Median kings (Sid. Carm. IX 27-31) or Ventidius, the great commander who defeated Parthians in the $1^{\text {st }}$ century BC (Sid. 
a lot about the past and present relations between Rome and Sasanian Persia. As a follower of Claudian ${ }^{78}$ he placed a lot of exotic ethnic and geographical names in laudatory passages of his poems. In two of Sidonius' panegyrics we also encounter the name of the Araxes. For the first time in the panegyric on the Emperor Avitus delivered 1 I 456:

\section{Indorum Ganges, Colchorum Phasis, Araxes}

Armeniae, Ger Aethiopum Tanaisque Getarum

Thybrinum tremuere meum.

(Sid. Carm. VII 74-76)

The catalogue of rivers is a part of the goddess Roma's speech on the subject of the glorious Roman history from the very beginnings to the times of Trajan (1. 51-117) $)^{79}$. Sidonius listed rivers that trembled at the Tiber, thus showing their recognition of the Roman power. The names with appositions fill two whole lines, a situation not untypical in late antique Latin poetry. The Araxes is connected with the name of Armenia being, in this catalogue, a clear-cut pars pro toto of this land. In contrast to the rivers Ger and Ganges (the former in Ethiopia, the latter in India) the Araxes can really be called a river acknowledging the Roman power, a fact not so obvious in the poetry of that age. These enumerations show the greatness of Rome in the good old days, pointing at the same time, that thanks to Avitus' rule, the empire is going to rejuvenate soon. ${ }^{80}$

In his panegyric on Anthemius, which Sidonius delivered 1 I 468, in the day of inauguration of consulate of the Emperor himself, we come across an interesting example of the reception of Claudian's poetry. Since Anthemius was installed on the western throne by eastern Emperor Leo I, the poet also had to praise Constantinople, as a new centre of Roman power in the East. Sidonius devoted a large segment of panegyric (1. 440-515) to the request of Roma to Aurora, so as to receive Anthemius as a ruler of the West:

Carm. II 456-457).

78 Kelly 2013: 171.

79 On the functions of the references to the Roman past in Sidonius' panegyrics see Guillaumin 2013.

80 Kelly 2013: 180-181. 


\section{Venio (desiste moveri}

Nec multum trepida), non ut mihi pressus Araxes

Imposito sub ponte fluat nec ut ordine prisco

Indicus Ausonia potetur casside Ganges, Aut ut tigriferi pharetrata per arva Niphatis

Depopuletur ovans Artaxata Caspia consul.

(Sid. Carm. II 440-445)

Another catalogue of rivers, ${ }^{81}$ again being a part of Roma's speech, reminds us of two aforementioned passages from Claudian's In Rufinum and De bello Gildonico. ${ }^{82}$ One deity (Roma) visits another (Aurora, personification of Constantinople) so as to obtain its consent in one particular issue. Before proceeding to this issue, we come across a long list of things that are not the goal of the suppliant. This list in panegyric on Anthemius is a detailed description of military relations between Rome and the eastern world (in particular with Parthians and Persians). Roma wants Anthemius as an emperor of the West, she does not want the onetime achievements to be repeated (this situation is duplicate of the plea of Roma to Jupiter in De bello Gildonico ${ }^{83}$ ). Roma gives up Eastern conquests to Aurora, a significant declaration of her own weakness. One of the renounced regions is Armenia symbolised as usual by the Araxes, that flows imposito sub ponte (1. 442), another employment of the Vergilian motif used later by Statius and Claudian. The bridge, being a symbol of Roman rule, is not needed now and from now on it will be Constantinople's, not Rome's task to be active in the East. The last reference to the Araxes then serves as a sign of resignation and disillusion after a few centuries of poetic announcements of the upcoming Roman conquests in the East ${ }^{84}$.

81 It is rather unclear if Sidonius treated Niphates as a mountain chain (as it should) or rather as a river. This mistake had been made before by Silius Italicus (Qui Gangen bibit et Pellaeo ponte Niphaten, Sil. XIII 765) and Claudian (Armenii Phasin, Parthi liquere Niphaten, Claud. III Cons. 72) - see also Syme 1987: 54-55.

82 L. Watson (1997: 252-256) expresses some reservations about this similarity, but in my opinion she points out the minor issues which do not change the general picture. 83 Another apparent similarity between Sidonius' panegyric and that poem of Claudian is the phrase Depopuletur ovans Artaxata Caspia consul (1. 445) being an unmistakeable reference to non ut proculcet Araxen / Consul ovans (Claud. Gild. 31-32). 84 Montone 2012: ad v. 440-442. On Constantinople in this poem of Sidonius see Kelly 2013: 187-189; Boshoff 2016. Boshoff does not analyse the passage on previ- 


\section{CONCLUSION}

As already seen from above, the Armenian river Araxes located at the edges of the oikoumene was frequently mentioned by Latin poets from the $1^{\text {st }}$ century $\mathrm{BC}$ to the $5^{\text {th }}$ century AD. Summing my analysis, I would like to draw some conclusions about the ways of referring to this river. First and foremost, in the existing corpus of Latin poetry the Araxes is mentioned 20 times.

\begin{tabular}{|l|l|l|}
\hline Period & Number & Authors \\
\hline Augustan Age & 4 & $\begin{array}{l}\text { Propertius (2), Vergil (1), } \\
\text { Pseudo-Tibullus (1) }\end{array}$ \\
\hline Neronian Age & 6 & Seneca (3), Lucan (3) \\
\hline Flavian Age & 3 & Statius (3) \\
\hline Late antiquity & 7 & Claudian (5), Sidonius (2) \\
\hline
\end{tabular}

The number of mentions grows steadily (taking into consideration the fact that the Augustan Age has a relatively greater amount of poetic production that survived) reaching its peak in late antiquity, which can be surprising, given the lack of activities conducted by the western Roman empire in the Caucasus region. In my opinion, the growth of interest in Armenian issues resulting in the greater frequency of references to the Araxes stemmed from the Armenian war in the times of Nero. The fact that Statius, writing to or about the people that took part in this conflict, mentioned that it too can be seen as a reason for the popularity of this motif in late antiquity, since Claudian was a careful reader of Statius and Sidonius a follower of Claudian. The analysis of the references to the Araxes can thus give us some useful pieces of information about the "internal" reception among the Latin poets.

Generally, the Araxes is usually mentioned as a pars pro toto of Armenia, which is a standard solution in the case of great rivers being used as a symbol of the land through which they flow. The meaning of Araxes as a frontier is also quite frequent. Sometimes it serves as a border river of the Roman empire, but sometimes it stands for frontier of Armenia, Persia/Parthia or - at the most general level - as an edge of the inhabited

ous military achievements of Rome in the East and his conclusions about the relations between Rome and Constantinople differ from mine. 
world. With only one exception of Seneca's Oedipus every mention of the Araxes is in some way connected to the issues of Roman politics, since crossing such a frontier was a symbol of conquest. ${ }^{85}$ The river is predominantly referred to in the context of Roman expansion in the East, though in some cases it is merely a laudatory ornament having nothing to do with real political and military achievements or even plans. Due to the strong links between Armenia and Parthia/Persia and the fact that Iranians were Romans' rivals in the struggle for this land, the Araxes was often placed in the Iranian rather than Armenian context (e.g. with the motif of so-called Parthian shot).

As regards the metrical questions, it is easily noticeable that the name Araxes in most cases creates the clausula of the line (both in hexameter and lyric measures). It is interesting that it is placed in a different position only in one poem, i.e. the elegy III 12 of Propertius, which is also - in total - the first mention of this river in Latin poetry. It seems that Roman poets used this name to fill in the line with a three-syllable word. Amongst twenty mentions poets used this name 10 times in the nominative, 7 times in the accusative, 2 times in the ablative and - only in the aforementioned poem of Propertius -1 time in the genitive. The issues of inflection remain in a close relation with the context of the phrases. When Araxes is a nominative, it serves as a subject of the sentence and has a predicate being a verb of movement (fluere $-2 \mathrm{x}$, ire $2 \mathrm{x}$ ), emotion (timere $-2 \mathrm{x}$, tremere $-1 \mathrm{x}$, exsultare $-1 \mathrm{x}$ ) or referring to service and coercion (famulari - 1x, pati cogi - 1x). The form Araxen (and Araxis used once in phrase Araxis aquam) is used as a direct object in the sentences showing the activities of drinking and obtaining water (potare $-3 \mathrm{x}$, bibere $-1 \mathrm{x}$, frangere $-1 \mathrm{x}$ ) or crossing (transire $-1 \mathrm{x}$, invadere $-1 \mathrm{x}$, proculcare $-1 \mathrm{x}$ ). The form Araxe is used twice as an ablative adverbial of limitation with verbs finire and venire.

We can observe patterns referring to the epithets and appositions of the river's name, because some tendencies are seen in the works of particular authors:

85 Cf. Arnaud 1993: 47 - “L'Euphrate et l'Araxes ne sont pas des frontières absolues, mais des obstacles sur la route de la conquête". 


\begin{tabular}{|l|l|}
\hline Author & Epithets and appositions \\
\hline Propertius & no epithet $(1) ;$ vincendus $(1)$ \\
\hline Vergil & pontem indignatus $(1)$ \\
\hline Pseudo-Tibullus & vagus $(1)$ \\
\hline Seneca & gelidus $(2)$; niveus $(1)$ \\
\hline Lucan & barbarus $(1) ;$ Armenius $(1) ;$ gelidus $(1)$ \\
\hline Statius & patiens Latii iam pontis $(1) ;$ pharetratus $(1) ;$ ferus $(1)$ \\
\hline Claudian & $\begin{array}{l}\text { Scythicus }(1) ; \text { pontemque pati cogetur }(1) ; \text { impacatus } \\
(1) ; \text { no epithet }(1) ; \text { extremus }(1)\end{array}$ \\
\hline Sidonius & no epithet $(1) ;$ pressus sub imposito ponte $(1)$ \\
\hline
\end{tabular}

Generally, the Araxes is pictured as cold (4 times), wild (3 times) or connected in a way with the Roman bridge (4 times). In the Augustan Age the epithets show the link with Roman activities in the East, whereas in the Neronian Age we observe an emphasis put on the temperature of the water (perhaps because of Seneca's and Lucan's interest in natural sciences). In late antiquity the epithets again show link with hopes of conquests, which is in line with the laudatory tendency present in panegyrics. However, only the epithet gelidus was used more than once (and only in the Neronian Age), which indicates the lack of one dominating association with the Araxes.

Summing up, it should be emphasised that quite frequent mentions of Araxes are part of the great interest in the exotic Oriental world, so pervasive in all of Latin poetry. It triggered different associations which were rather in line with the general tendency towards the employment of riverine names in Greek and Latin literature. As it is often the case in Roman literature, the Oriental geographical names are connected with the Roman policy in the East, especially with expansion. The Araxes is used exactly in that manner. It brings to mind the past, present or future conquests in Armenia that was a land of great interest for Romans competing with Parthia/Persia for control of the entire region of Anatolia, Caucasus and Mesopotamia. As such, the Araxes was used frequently in panegyrical poems oriented to extol the emperor: it was Vergil who paved the way for such a use. The authors of the Augustan and Neronian Age mentioned the Araxes in the circumstances of Roman involvement in Armenia. Later poets wrote about this river in the times when the Empire was not active there. Nevertheless, the weaker the Roman position 
in Armenia (and not only there), the more often poets like Claudian and Sidonius wrote about the Araxes in their political works.

\section{REFERENCES}

\section{Primary sources and commentaries}

Appendix Tibulliana, ed. H. Tränkle, Berlin - New York 1990.

Claudian, Volume I, ed. M. Platnauer, Cambridge - London 1990.

Claudian, Volume II, ed. M. Platnauer, Cambridge - London 1998.

Cuzzone T., L'invettiva contro Gildone. Motivi di propaganda politica e prassi letteraria (Per un commento a Claud. carm. 15), Università degli studi di Trieste (diss.) 2006/2007.

Levy H.L., Claudian's In Rufinum. An Exegetical Commentary, London - Beccles 1971.

Marcus Annaeus Lucanus, De bello civili libri X, ed. D.R. Shackleton-Bailey, Berolini et Novi Eboraci 2009.

Montone F., Sidonio Apollinare. Carmi 1 e 2. Praefatio e Panegirico per Antemio. Introd., trad., comm. ed Appendici, Università degli studi di Napoli "Federico II" (diss.) 2012.

P. Papinius Statius, Thebais, eds. A. Klotz, T.C. Klinnert, Leipzig 1973.

Propertius, Elegies I-IV, ed. with introd., comment. L. Richardson, jr, Norman 1977.

Seneca, Phaedra, ed. M. Coffey, R. Mayer, Cambridge 1990.

Sidonius, Poems and Letters. Volume I. Poems, Letters, Books I-II, ed. W.B. Anderson, Cambridge - London 1963.

Statius, Silvae 5, introd., transl. and comment. B. Gibson, Oxford 2009.

Virgil, Aeneid. Book VIII, ed. K.W. Gransden, Cambridge 1976.

Watson L., Sidonius Apollinaris' Carmina 1 and 2. A Commentary, University of London (diss.) 1997.

\section{Secondary sources}

Arnaud P., 1993, 'Frontière et manipulation géographique. Lucain, les Parthes et les Antipodes', [in:] La Frontière. Séminaire de recherche sous la direction d'Yves Roman, Lyon, pp. 45-56.

Axer J., 1991, Filolog $w$ teatrze, Warszawa.

Babnis T., 2017, 'Augustan Poets on the Roman-Parthian Treaty of 20 BC', Classica Cracoviensia 20, pp. 5-43, https://doi.org/10.12797/CC.20.2017.20.01. 
Babnis T., 2018a, 'Iranian Themes in the Poetry of Statius', Classica Cracoviensia 21, pp. 5-29, https://doi.org/10.12797/CC.21.2018.21.01.

Babnis T., 2018b, 'Sive aliquid pharetris Augustus parcet Eois. Wschodnia polityka Rzymu w poezji Propercjusza', Roczniki Humanistyczne 66/3, pp. 7-27, https://doi.org/10.18290/rh.2018.66.3-1.

Benton C., 2003, 'Bringing the Other to Center Stage. Seneca's "Medea" and the Anxieties of Imperialism', Arethusa 36/3, pp. 271-284, https://doi. org/10.1353/are.2003.0019.

Bernstein N.W., 2011, 'The Dead and their Ghosts in the Bellum Civile. Lucan's Visions of History', [in:] Brill's Companion to Lucan, P. Asso (ed.), Leiden Boston, pp. 257-279, https://doi.org/10.1163/9789004217096_014.

Bexley E., 2014, 'Lucan's Catalogues and the Landscape of War', [in:] Geography, Topography, Landscape. Configurations of Space in Greek and Roman Epic, M. Skempis, I. Ziogas (ed.), Berlin - Boston, pp. 373-403.

Blockley R.C., 1987, 'The Division of Armenia between the Romans and the Persians at the End of the Fourth Century A.D.', Historia: Zeitschrift für Alte Geschichte 36/2, pp. 222-234.

Boshoff L., 2016, 'Looking Eastwards. The Regina Orientis in Sidonius Apollinaris' Carmen 2', [in:] From Constantinople to the Frontier. The City and the Cities, N.S.M. Matheou et al. (ed.), Leiden - Boston, pp. 13-24, https://doi. org/10.1163/9789004307742_003.

Boyle A.J., 1997, Tragic Seneca. An Essay in the Theatrical Tradition, LondonNew York.

Brodka D., 1998, Die Romideologie in der römischen Literatur der Spätantike, Frankfurt am Main.

Campbell B., 2012, Rivers and the Power of Ancient Rome, Chapel Hill.

Cary M., Warmington E.H., 1968, Starożytni odkrywcy, transl. B. Wojciechowski, Warszawa.

Casamento A., 2013, 'In trionfo sull'Arasse. A proposito di Luc. Phars. 1,19', Paideia 68 , pp. 57-78.

Cattin A., 1963, 'La géographie dans les tragédies de Sénèque', Latomus 22/4, pp. 685-703.

Clauss J.J., 1988, 'Vergil and the Euphrates Revisited', The American Journal of Philology 109/3, pp. 309-320, https://doi.org/10.2307/294887.

Dueck D., 2012, Geography in Classical Antiquity, Cambridge, https://doi. org/10.1017/CBO9781139027014. 
Feldherr A., 2014, 'Viewing Myth and History on the Shield of Aeneas', Classical Antiquity 33/2, pp. 281-318, https://doi.org/10.1525/CA.2014.33.2.281.

Fischer R., 1968, Das ausseritalische geographische Bild in Vergils Georgica, in den Oden des Horaz und in den Elegien des Properz, Zürich.

Fisher W.B., Bosworth C.E., 1986, Araxes, [in:] Encyclopedia Iranica online.

Galinsky K., 1969, 'The Triumph Theme in the Augustan Elegy', Wiener Studien 3, pp. 75-107.

Garambois-Vasquez F., 2007, Les invectives de Claudien. Une poétique de la violence, Bruxelles.

Grant M., 2000, 'Seneca's Tragic Geography', Latomus 59/1, pp. 88-95.

Guillaumin J.-Y., 2013, 'Rappel de l'histoire et invitation à l'action dans les Panégyriques de Sidoine Apollinaire', Dialogues d'histoire ancienne. Supplément $n^{\circ} 8$, pp. 93-107, https://doi.org/10.3917/dha.hs80.0093.

Hardie Ph., 1986 Virgil's Aeneid. Cosmos and Imperium, Oxford.

Harrison S.J., 1997, 'The Survival and Supremacy of Rome. The Unity of the Shield of Aeneas', The Journal of Roman Studies 87, pp. 70-76, https://doi. org/10.2307/301369.

Heckenlively T.S., 2013, "Clipeus Hesiodicus. "Aeneid" 8 and the "Shield of Heracles", Mnemosyne, Fourth Series 66/4-5, pp. 649-665, https://doi. org/10.1163/156852512X617632.

Hillman T.P., 1996, ‘Pompeius ad Parthos?', Klio 78/2, pp. 380-399, https://doi. org/10.1524/klio.1996.78.2.380.

Hodges G.W.Q., 2004, Ethnographic characterization in Lucan's 'Bellum Civile', Ohio State University (diss.).

Jenkyns R., 1993, 'Virgil and the Euphrates', The American Journal of Philology 114/1, pp. 115-121, https://doi.org/10.2307/295386.

Jones P.J., 1999, Agmen aquarum. Reading Rivers in Their Roman Cultural Context, Harvard University (diss.).

Kelly G., 2013, 'Sidonius and Claudian', [in:] New Approaches to Sidonius Apollinaris, J.A. van Waarden, G. Kelly (ed.), Leuven - Paris - Walpole, pp. 171-194.

Manolaraki E., 2013, Noscendi Nilum Cupido. Imagining Egypt from Lucan to Philostratus, Berlin - Boston, https://doi.org/10.1515/9783110297737.

Mendell C.W., 1942, 'Lucan's Rivers', Yale Classical Studies 8, pp. 3-22.

Nabel J., 2019, 'Lucan's Parthians in Nero's Rome', Classical Philology 114, pp. 604-625, https://doi.org/10.1086/705162. 
Parkes R., 2005, 'Model Youths? Achilles and Parthenopaeus in Claudian's Panegyrics on the Third and Fourth Consulships of Honorius', Illinois Classical Studies 30, pp. 67-82.

Pogorzelski R., 2011, 'Orbis Romanus. Lucan and the Limits of the Roman World', Transactions of the American Philological Association 141/1, pp. 143-170, https://doi.org/10.1353/apa.2011.0000.

Romm J.S., 1992, The Edges of the Earth in Ancient Thought, Princeton, https:// doi.org/10.1515/9780691201702.

Scodel R.S., Thomas R.F., 1984, 'Virgil and the Euphrates', The American Journal of Philology 105/3, p. 339, https://doi.org/10.2307/294999.

Sherwin-White A.N., 1984, Roman Foreign Policy in the East 168 B.C. to A.D. 1, London.

Syme R., 1987, 'Exotic Names, Notably in Seneca's Tragedies', Acta Classica 30, pp. 49-64.

Thomas R.F., 1982, Lands and Peoples in Roman Poetry. The Ethnographical Tradition, Cambridge.

Walde Ch., 2007, 'Eine poetische Hydrologie. Flüsse und Gewässer in Lucans Bellum Civile', [in:] Antike Naturwissenschaft und ihre Rezeption, J. Althoff, B. Herzhoff, G. Wöhrle (Hrsg.), Trier, pp. 59-84.

Ware C., 2004, 'Gildo tyrannus. Accusation and Allusion in the Speeches of Roma and Africa', [in:] Aetas Claudianea, W.W. Ehlers et al. (ed.), Leipzig, pp. 96103, https://doi.org/10.1017/CBO9781139004152.

Ware C., 2012, Claudian and the Roman Epic Tradition, Cambridge.

Weeda L., 2015, Vergil's Political Commentary in the Eclogues, Georgics and Aeneid, Warsaw - Berlin, https://doi.org/10.1515/9783110426427.

Wellesley K., 1968, 'Virgil's Araxes', Classical Philology 63/2, pp. 139-141, https://doi.org/10.1086/365350.

Wissemann M., 1982, Die Parther in der augusteischen Dichtung, Frankfurt am Main - Bern. 